DOI: https://doi.org/10.24867/12BE05Stanarevic

\title{
ANGULAR КОМПОНЕНТА ЗА КОНТРОЛУ ПРИСТУПА БАЗИРАНУ НА КОРИСНИЧКИМ УЛОГАМА
}

\section{ANGULAR COMPONENT FOR ROLE-BASED ACCESS CONTROL}

\author{
Јелена Станаревић, Факултет техничких наука, Нови Сад
}

\section{Област - РАЧУНАРСТВО И АУТОМАТИКА}

Кратак садржај - У раду је описана Angular компонента која омогућује динамичку ауторизацију на клијентској страни апликације. Ауторизачија, односно, контрола приступа базирана је на RBAC (Role-based Access Control) моделу. Angular компонента представља проширење постојећих могућности Angular програмског оквира и омогућава уклањање/приказиване компоненти и делова компоненти, као $u$ дозволу/забрану измене или уноса одређених поља у оквиру компоненти. Верификација креиране Angular компоненте приказана је кроз информациони систем за физикалну терапију.

Кључне речи: Kontrola pristupa, RBAC, Angular framework, dinamička autorizacija

Abstract - This paper describes the Angular component that is responsible for dynamic authorization on the client side of the application. Authorization (access control) is based on the RBAC (Role-based Access Control) model. The Angular component is an extension of the existing capabilities of the Angular framework and allows the removal / display of components and parts of components, as well as the permission / prohibition of modification or entry of certain fields within the components. Verification of the created Angular component is presented through the information system for physical therapy.

Keywords: Access control, RBAC, Angular framework, dynamic authorization

\section{1. УВОД}

Често ce Role-based Access Control модел контроле приступа имплементира на серверској страни апликације. Међутим, овакав приступ има велику ману, а то је брзина којом се проверава да ли корисник има или нема право приступа делу система. Приступ имплементиран у оквиру система за физикалну терапију, јесте динамичка ауторизација на клијентској страни апликације. Претходно споменута брзина провере права приступа корисника се знатно повећава са овим приступом.

\section{НАПОМЕНА:}

Овај рад проистекао је из мастер рада чији ментор је био проф. др Горан Сладић.
У оквиру овог рада биће описана и презентована посебно креирана Angular компонента која је одговорна за примену контроле приступа базиране на корисничким улогама (Role-based Access Control, $R B A C)$, односно, за динамичко генерисање различитих компоненти и делова компоненти у складу са правима приступа.

\section{2. КОНТРОЛА ПРИСТУПА У ИНФОРМАЦИОНИМ СИСТЕМИМА}

У области информационе безбедности (енгл. Information Security) контрола приступа подразумева праксу спречавања неовлашћеног приступа, коришћења, откривања, модификације, снимања или уништавања информација [1].

\subsection{Role-based access control}

Концепт контроле приступа заснован на улогама (енгл. Role-based access control, RBAC) јавио се са увођењем вишекорисничких online система и апликација око 1970. године. Централно место у оквиру RBAC модела заузимају појмови и односи улога, дозвола и корисника. Дозволе су везане за улоге, док се корисницима те улоге додељују.

Улоге се креирају у складу са различитим корисничким функцијама у организацији или компанији. Дакле, корисницима се додељују улоге у складу са одговорностима и надлежностима које имају у оквиру компаније. С обзиром да су промене у оквиру било ког информационог система неизбежне, корисницима је могуће додељивати друге улоге у току времена.

Такође, улогама могу да се уклањају претходне и додају нове дозволе [1]. У оквиру организације улоге се ретко мењају, док се дозволе и корисници чешће могу мењати. Однос између улога, корисника и дозвола приказан је на слици 2.1.

Основна предност RBAC модела јесте управо централизована администрација улога, дозвола и корисника.

Централизована администрација обезбеђује једноставније управљање у смислу да се све своди на додељивање одговарајућих улога корисницима, за разлику од ACL листи (енгл. Access Control Lists). У оквиру ових листи неопходно је да се за сваког новог корисника прође кроз сваки ресурс система и његовој листи придружи корисник са одговарајућим правом које има над тим ресурсом [1]. 


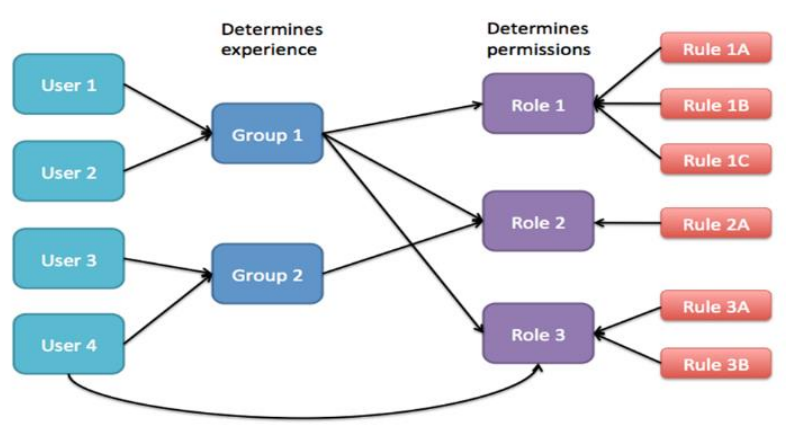

Слика 2.1. Однос корисника, група, улога и дозвола [1]

\section{3. СПЕЦИФИКАЦИЈА КОМПОНЕНТЕ ЗА КОНТРОЛУ ПРИСТУПА}

У оквиру овог поглавља биће презентована улога компоненте за контролу приступа, али без детаља око саме имплементације.

\section{1. Постојеће могућности Angular framework-a}

Angular представља платформу и програмски оквир (енгл. framework) за израду клијентске стране интернет апликација. Програмски оквир је направљен у JavaScript-у и омогућава израду тзв. single-page апликација користећи ТурeScript и HTML. Angular нуди још једну могућност динамичке измене структуре HTML фајла одређене компоненте уз помоћ тзв. структуралних директива. Структуралне директиве, попут *ngIf или *ngFor омогућавају да се мења изглед Document Object Model стабла дефинисаног у оквиру HTML странице у зависности од вредности појединих података доступних конкретној компоненти [2]. *ngIf директива представља уграђену директиву програмског оквира, која уклања или креира део Document Object Model стабла. Претходно наведено зависности од резултата валидације израза на који се односи (слика 3.1) [2].

$<$ div *ngIf="condition" $>$ Content to render when condition is true. $</$ div $>$

\section{Слика 3.1 - Пример примене *ngIf директиве}

\section{2. Модел компоненте за контролу приступа}

На сликама у наставку биће приказан део UML дијаграма класа за клијентску страну апликације. Конкретно, приказане су постојеће компоненте у оквиру Angular програмског овкира, сервисне и модел класе, као и везе између њих. Комуникација ових компоненти је кључна у реализацији динамичке ауторизације.

На слици 3.2. приказан је део UML дијаграма класа који се односи на компоненте клијентске стране које се инстанцирају приликом пријаве на систем, везе између њих, као и везе компоненти са сервисним класама. LoginComponent компонента, путем dependency injection концепта, садржи везе ка уграђеним компонентама Angular програмског оквира [2].

Такође, садржи везе према сервисима задуженим првенствено за управљање процесом пријаве корисника на систем (AuthService и PermissionsService). AuthService у себи садржи везу ка JwtService сервис класи. Везе које садржи LoginComponent компонента омогућавају јој да користи све методе претходно набројаних сервиса. JwtService сервис класа омогућава управљање JWT токенима. У оквиру система за физикалну терапију имплементирана је аутентификација учесника система уз помоћ JSON Web Токена или, скраћено, JWT [3].

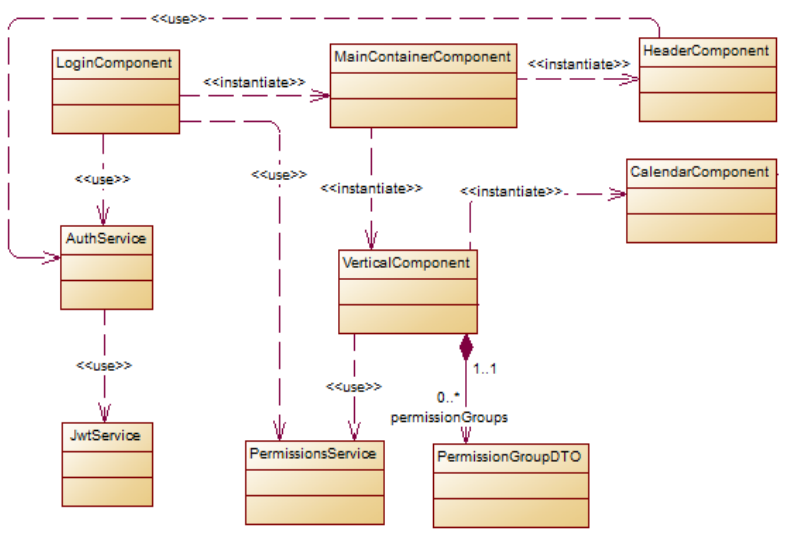

Слика 3.2 - Део UML дијаграма класа који се односи на компоненте одговорне за пријаву корисника на систем

На слици 3.3 приказан је део UML дијаграма класа који се односи на везе између компоненти приказа и директива које омогућавају приказ/уклањање компоненти и делова компоненти. Директиве задужене за динамичку ауторизацију у систему су IsGrantedDirective и Is GroupGrantedDirective.

Обе су путем dependency injection концепта повезане ca PermissionManagerService сервис класом, која, преко комуникације са PermissionsService сервис класом, омогућава преузимање и проверавање дозвола које улоговани корисник поседује. CalendarComponent компонента такође користи IsGrantedDirective директиву и има везу ка њој.

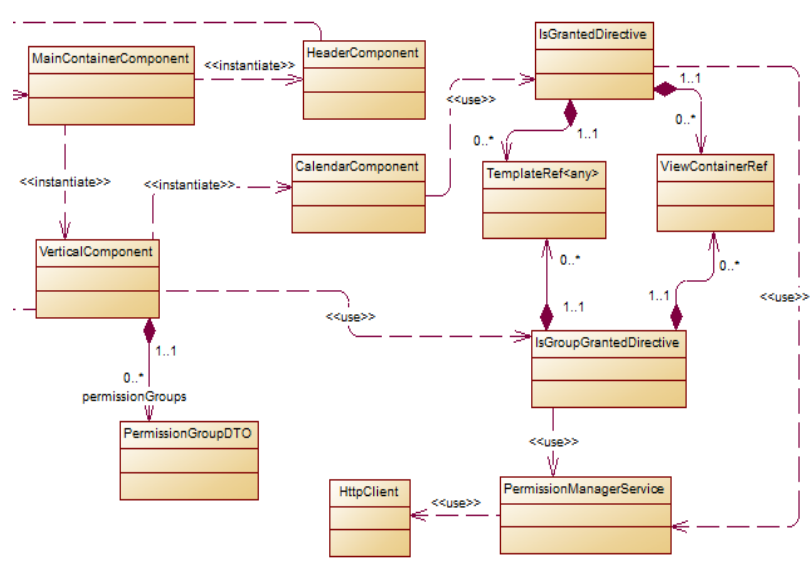

Слика 3.3 - Део UML дијаграма класа који се односи на везу компоненти са директивом

IsGrantedDirective и IsGroupGrantedDirective, преко инстанци TemplateRef<any> и ViewContainerRef, омогућавају да се део HTML садржаја креира, обрише, или да се забрани, односно, омогући измена тог садржаја. 


\section{3. Интеракција компоненте за контролу приступа са компонентама система}

На сликама у наставку биће презентован целокупан процес и логика иза креирања/уклањања компоненти и делова компоненти, као и омогућавања/забране уноса и измене појединих поља у складу са скупом дозвола пријављеног корисника. На слици 3.4 приказана је комуникација компоненти и сервиса приликом пријаве корисника на систем. Регистровани корисник уноси емаил и лозинку у одговарајућа поља LoginComponent компоненте, која од датих информација формира објекат типа LoginDTO и прослеђује формирани објекат AuthService сервис класи [4].

Ова класа комуницира са серверском страном апликације, ради верификовања исправности унетих креденцијала корисника. Серверска страна је у дијаграмима секвенци приказана по тзв. Black-Box принципу. Овај принцип подразумева да се одређени систем или део система представи само преко улазних и излазних параметара, без самих детаља имплементације и начина функционисања истог [5]. Комуникација са серверској страном обавља се путем НTTP POST захтева.

Након провере послатих креденцијала, серверска страна има два алтернативе. Једна подразумева да унети емаил и/или лозинка нису исправни и у том случају сервер враћа null вредност и клијентска страна обавештава корисника о неисправности креденцијала. Друга алтернатива подразумева да сервер одговори са формираним JWT токеном, као потврдом успешне пријаве корисника на систем [3].

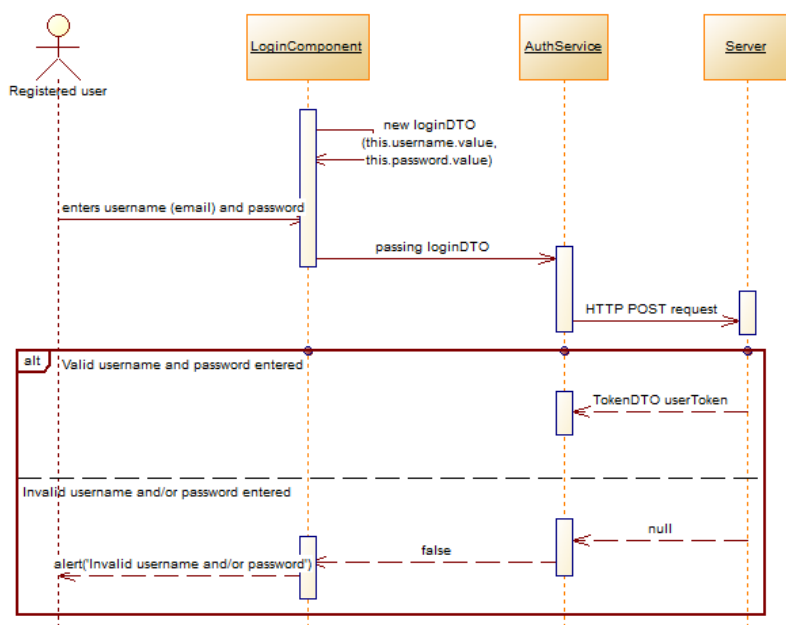

Слика 3.4 - пријава корисника на систем

Преузети JWT токен се шаље од AuthService сервис класе до JwtService сервис класе која смешта тај токен y locale storage интернет претраживача. Информација о успешно ускладиштеном JWT токену враћа се до LoginComponent компоненте. Даље следи иницијализација сервисних класа и компоненти почетне странице апликације [3]. PermissionsService сервис класа добавља објекат ауторизације.

Наведени објекат садржи информације о свим улогама, дозволама и групама дозвола корисника путем комуникације са серверском страном (слика 3.5).

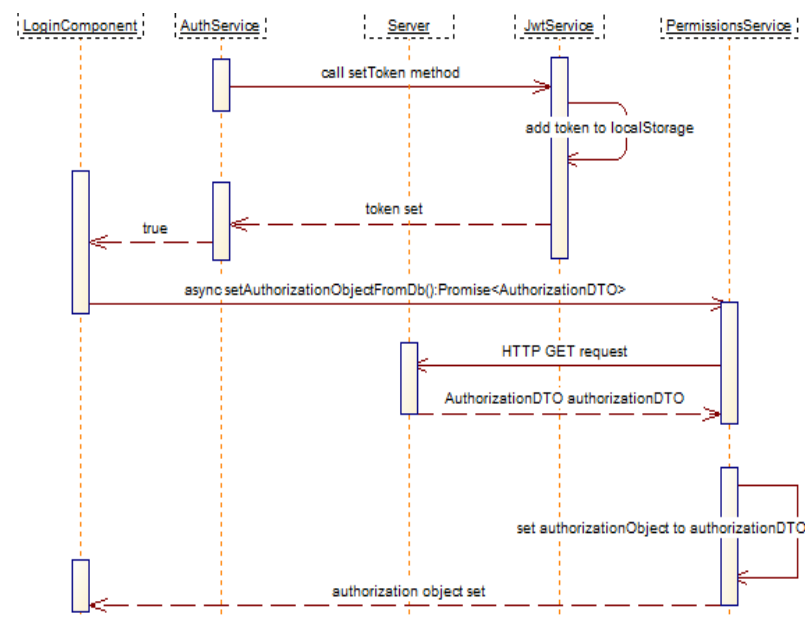

Слика 3.5 Сиенарио успешне пријаве корисника на систем

Иницијализација VerticalComponent компоненте, која репрезентује вертикални мени почетне странице и попуњава се линковима за извршавање појединих операција (додавање новог пацијента, измена одређеног термина, итд.) врши се путем комуникације ca IsGratedDirective и IsGroupGrantedDirective директивама. Попуњавање компоненте линковима зависи од скупа дозвола пријављеног корисника. Најпре се кроз комуникацију са PermissionsService сервис класом (последично и са серверском страном апликације), добављају одвојено листа свих група дозвола и мапа груписаних свих дозвола у систему.

С обзиром да су дозволе распоређене по групама у облику мапе у компоненти VerticalComponent, приликом њене иницијализације најпре се проверава да ли корисник има право да приступа одређеној групи дозвола. Та провера врши се преузимањем по једне из листе свих група и комуникацијом са IsGroupGrantedDirective директивом. Споменута директива се обраћа PermissionManagerService сервис класи која ће, на основу претходно преузетог authorizationDTO објекта од PermissionsService класе (види слику 3.5) вратити директиви информацију о томе да ли корисник поседује прослеђену групу дозвола [3]. У случају да корисник поседује прослеђену групу дозвола, HTML садржај се креира, док се у супротном брише у оквиру директиве (слике 3.6 и 3.7$)$.

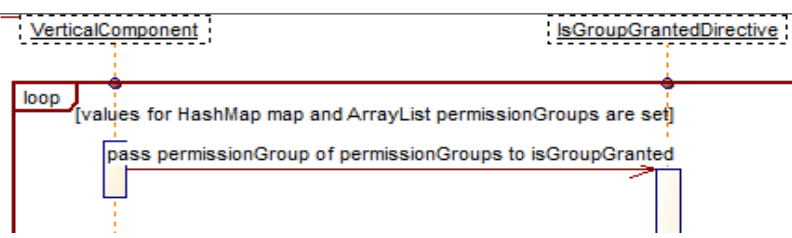

Слика 3.6 - Слање по једне групе дозвола

Пре него што се провери да ли корисник поседује наредну групу, постојећа група која је анализирана се користи као кључ у мапи у оквиру VerticalComponent компоненте. На основу кључа преузимају се и проверавају дозволе везане за исти. 


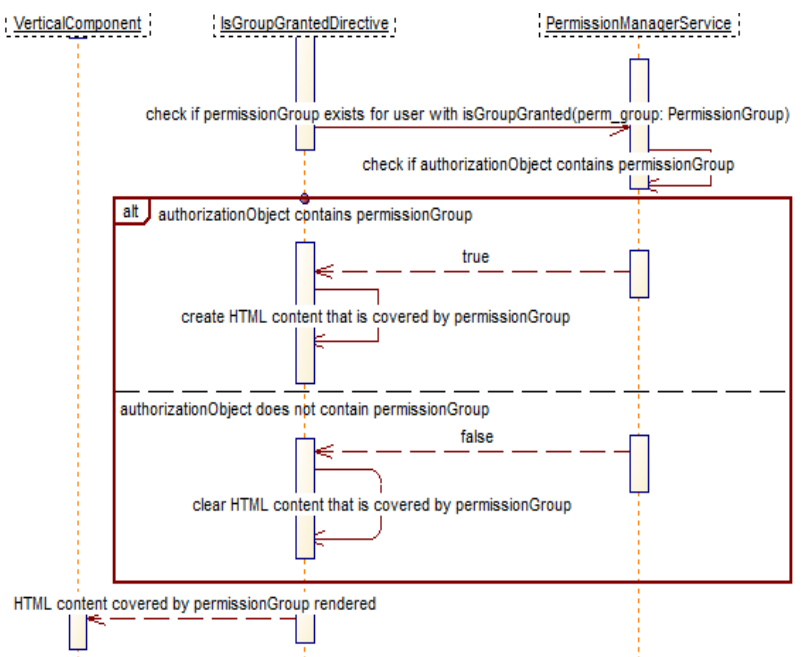

Слика 3.7 - Proveravanja prisustva prosleđene grupe dozvola

У овој ситуацији VerticalComponent компонента комуницира са IsGrantedDirective директивом, прослеђујући јој дозволу по дозволу. Директива у комуникацији са PermissionManagerService сервис класом проверава присуство сваке дозволе у скупу дозвола пријављеног корисника. У складу с тим PermissionManagerService сервис класа враћа вредности true или false уколико корисник поседује, односно, не поседује дозволу у оквиру свог скупа дозвола. IsGrantedDirective директива ће у складу са тим креирати или уклонити одређени HTML садржај.

\section{4. ИМПЛЕМЕНТАЦИЈА КОМПОНЕНТЕ ЗА КОНТРОЛУ ПРИСТУПА}

\section{1. Провера права приступа ресурсу система на клијентској страни}

Константно пресретање захтева и провера скупа дозвола које корисник са одређеном улогом има над сваким ресурсом представља безбедан и поуздан начин имплементације ауторизације. Међутим, овај начин имплементације је знатно спорији од алтернативе која ће бити презентована у овом одељку и која постоји у систему. Алтернатива подразумева динамичку ауторизацију на клијентској страни апликације, односно, проверу скупа дозвола над ресурсима система без учешћа пресретача (енгл. Interceptor) на серверској страни.

\subsection{1 Динамичка ауторизација у систему за физикалну терапију}

У систему креирана је нова директива као проширење постојећих, која омогућава динамичко проверавање дозвола пријављеног корисника и приказ или уклањање компоненти или делова компоненти, као и забрану/дозволу измене појединих поља. Директива је означена ca@Decorater(\{selector: ‘[appIsGranted]'\}). Као и код структуралних директива, примена кода нове директиве подразумева да се HTML садржај обухвати са селектором директиве, односно, у овом случају - ca *appIsGranted. Кључне елементе у оквиру директиве представљају ViewContainterRef и TemplateRef, који су уједно и поља у оквиру исте. ViewContainterRef представља контејнер у који се може додати прикази дефинисани TemplateRef шаблоном.

Тих приказа може бити један или више. Овај шаблон садржи део Document Object Model стабла у оквиру HTML фајла конкретне компоненте. Тај део ће бити генерисан, елиминисан или ће ce омогућити/ онемогућити унос и измена истог у зависности од скупа дозвола пријављеног корисника.

\section{6. ЗАКЉУЧАК}

У раду су описани основни појмови везани за контролу приступа, са посебним нагласком на Rolebased Access Control или RBAC модел контроле приступа. Овај модел описан је у посебном одељку. Спецификација Angular компоненте, односно, директиве, одговорне за динамичку ауторизацију, налази се у оквиру одвојеног поглавља. У оквиру истог поглавља презентоване су постојеће могућности Angular програмског оквира у погледу динамичког генерисања компоненти и делова компоненти, затим презентовање компоненте путем дела UML дијаграма класа и одређених UML дијаграма секвенци.

Кроз пример генерисања вертикалног менија објашњена је примена креиране директиве и начин на који компоненте, сервиси и директиве комуницирају у циљу реализације динамичке провере дозвола корисника у систему. Потенцијална проширења представљеног решења би могла бити могућност креирања нових дозвола у систему и њихово додељивање постојећим или потпуно новим улогама. Затим могућност да се привремено модификује постојећи скуп дозвола (нпр. да се поједине дозволе ипак онемогуће уколико се у оквиру система дода потпуно нови корисник, без искуства у раду са системом, са улогом администратора).

\section{7. ЛИТЕРАТУРА}

[1] Role-based Access Control, Ravi S. Sandhu, http://www.profsandhu.com/articles/advcom/adv_comp_rba c.pdf

[2] Izrada web aplikacije putem Angulara 6 razvojnog okvira, F Tuđan,

https://repozitorij.unin.hr/islandora/object/unin:2023/datastre am/PDF/download

[3] Security of JSON Web Tokens (JWT), https://cyberpolygon.com/materials/security-of-json-webtokens-jwt/

[4] Create Data Transfer Objects (DTOs), https://docs.microsoft.com/en-us/aspnet/webapi/overview/data/using-web-api-with-entityframework/part-5

[5] Black-Box Model, https://www.sciencedirect.com/topics/engineering/blackbox-model

\section{Кратка биографија:}

Јелена Станаревић рођена је 28.07.1995. године у Новом Саду. Завршила је Основну школу "Васа Стајић”, а потом и Гимназију ”Јован Јовановић Змај” (природно-математички смер), у Новом Саду. Гимназију је завршила 2014., и исте године је уписала Факултет техничких наука у Новом Саду, одсек Рачунарство и аутоматика. Завршила је основне академске студије 27.09.2018. 